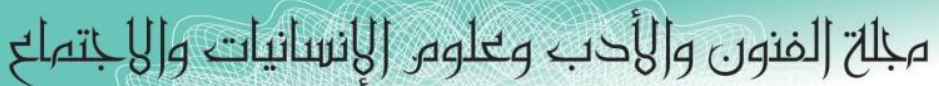

Journal of Arts, Literature, Humanities and Social Sciences

ISSN online: 2414 - 3383

ISSN print: 2616 - 3810

العدد (4O) تموز - يوليو 2019

\title{
الصورة الشعرية في شعر الشريف المرتضى (ت 436هـ)
}
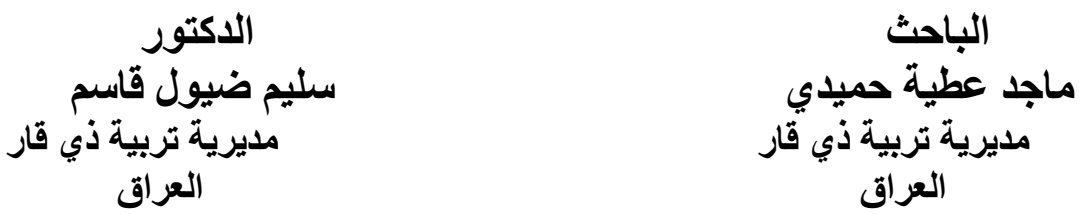

الخلاصة

للصورة الثعرية دور ها الكبير في رسم لوحة فنية لها أثرها في المتلقي، و عليها و على بعض الأركان الأخرى

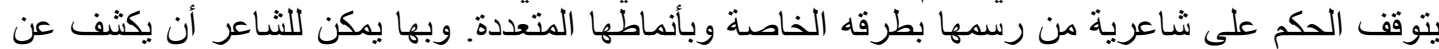

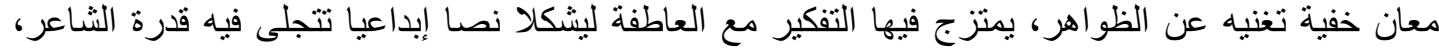

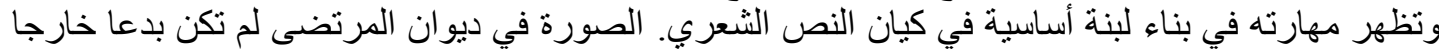

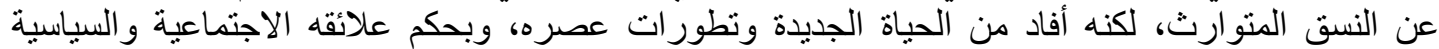

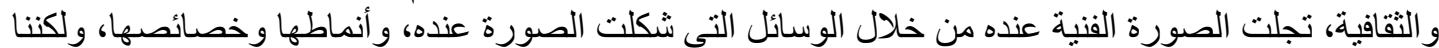

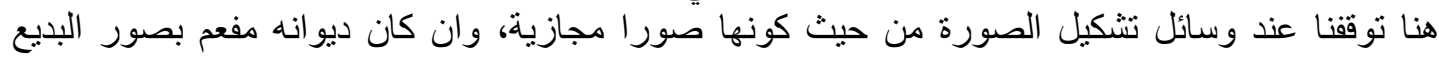

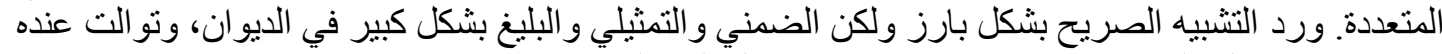
الاستعار ات بشكل ملحوظ في فصائد متعددة، وكان يميل إليها إلى حد كبير.

\section{The Poetic Picture in the Sharif Al-Mortada Poetry (Died 436 H)}

\begin{abstract}
The poetic image has a great role in painting a painting that has an impact on the recipient. On it and on some other pillars, the judgment depends on the poetic nature of its own ways and patterns. In which the poet can reveal hidden meanings that enrich him from phenomena, in which he combines thinking with emotion to form a creative text that reflects the poet's ability, and shows his skill in building a basic building block in the poetic text. The picture in the office of Al-Murtada was not an innovation out of the inherited pattern, but it benefited from the new life and the developments of its era, and by virtue of its social, political and cultural relations, its artistic image was manifested through the means that formed the image and its patterns and characteristics. As it is metaphorical images, although his office is full of multiple images. The explicit, but implicit, representational and eloquent metaphor was most vividly echoed in the Diwan, and metaphors were prominently featured in several poems, and he was greatly inclined to them.
\end{abstract}




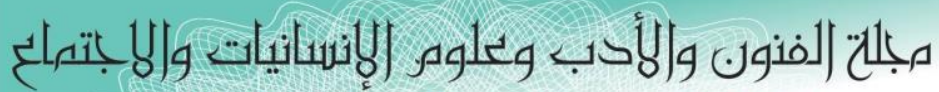
Journal of Arts, Literature, Humanities and Social Sciences

ISSN online: 2414 - 3383

ISSN print: 2616 - 3810

\section{العدد (4O) تموز - يوليو 2019}

الشريف المرتضى: سيرة حياته ومكانته:

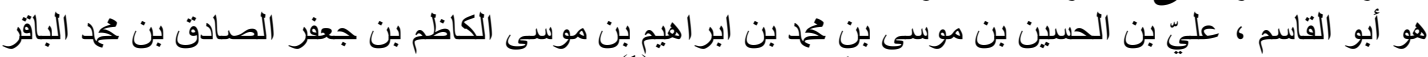

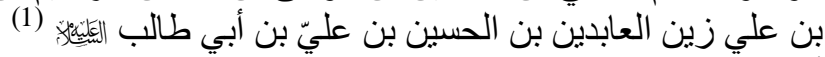
ألقابه : الثريف المرتضى، ونقين العابن بن العلوية و والطالبيين وشيخ الثيعة و علم الهدى وذو المجدين و الأجل و الطاهر

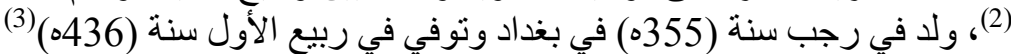

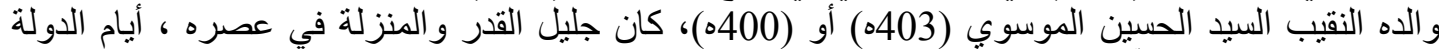

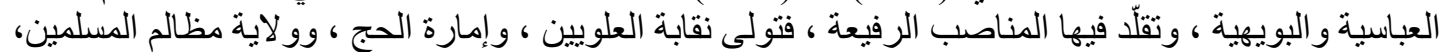

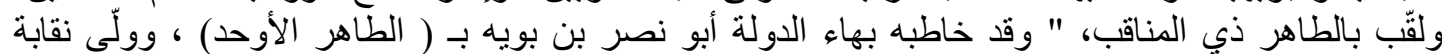

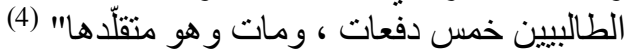

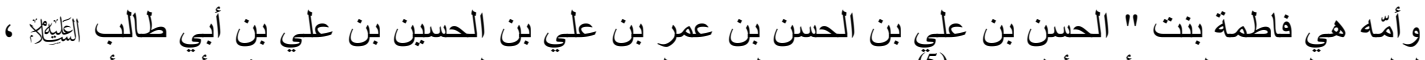

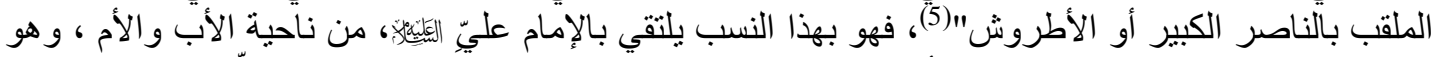

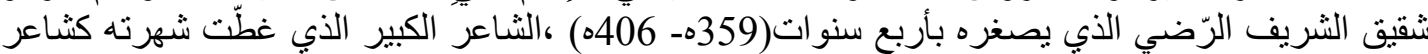
على خلفياته الأدبية في التأليف في مجالات شتى، كما أنّ أخاه المرتضى عُرف فقيهاً عالما متكلما أكثر منه

شاعر اً.

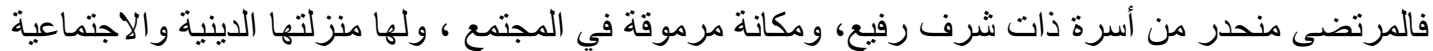

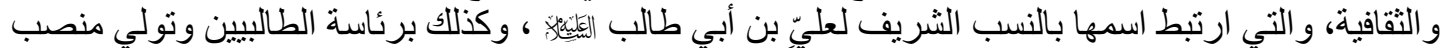

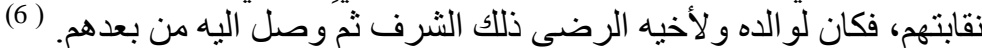

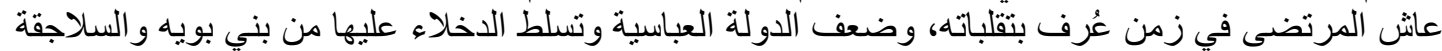

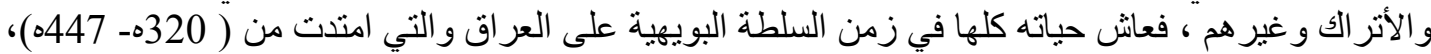

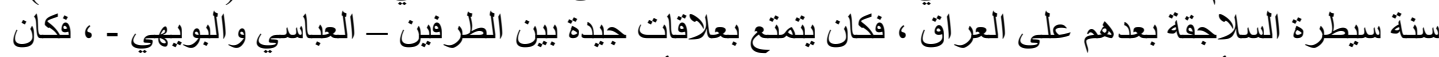

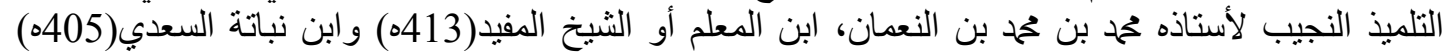
و وغير هما. وكان يمتلك موهبة الشعر ويجيده كأخيه الثريف الرضي ، لكنه اشتهر فقيها متكلما، مع أنه شاعر مفلق كأخيه

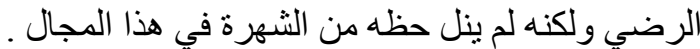
وقد ألمّت بعض الكضنه لمبادر بجو انب حياته وسيرته العلمية والأدبية و لاسيّما في السنوات الأخيرة ، لذلك نقتصر

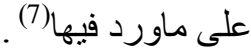

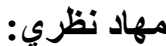

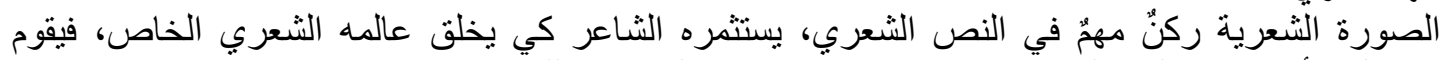

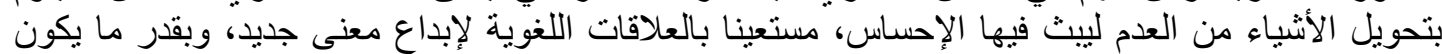

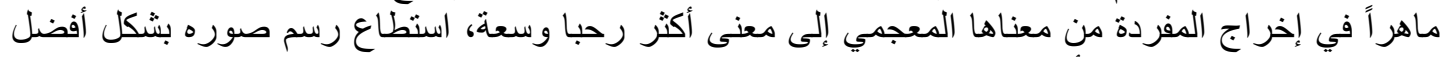

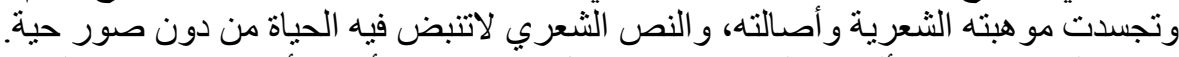

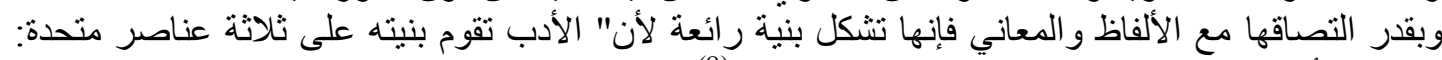

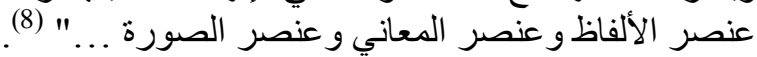

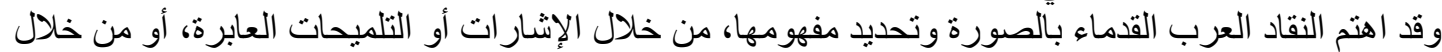

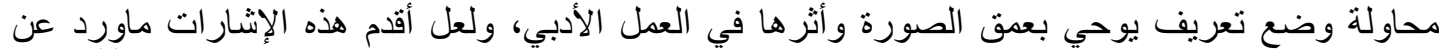

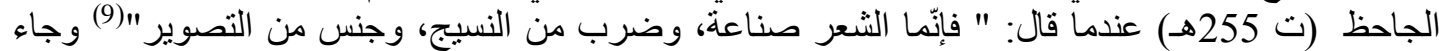

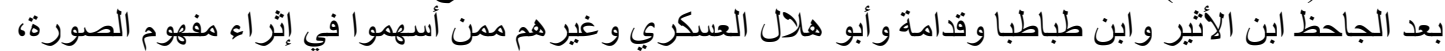

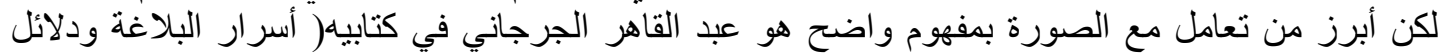

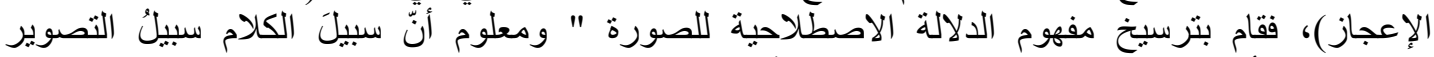

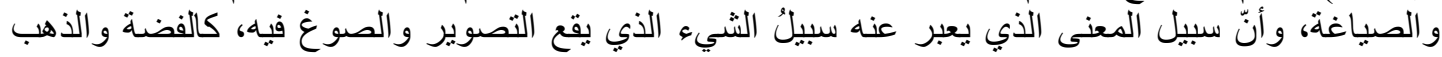




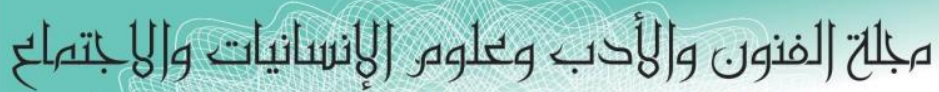
Journal of Arts, Literature, Humanities and Social Sciences

ISSN online: 2414 - 3383

ISSN print: 2616 - 3810

\section{العدد (4O) تموز - يوليو 2019}

يصاغ منهما خاتم أو سوار...." (10)، فلم يهمل عبد القاهر الأثر النفسي وأهميته في تشكيل الصورة؛ فاستند في

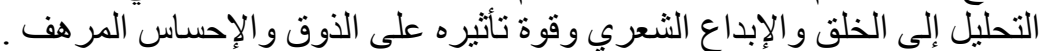

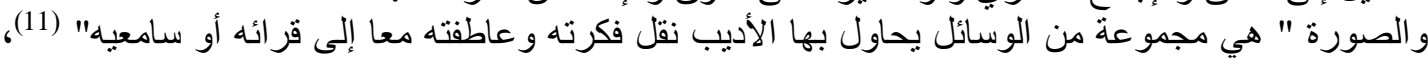

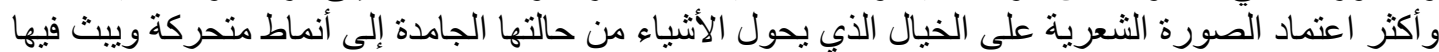

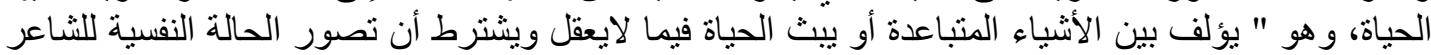

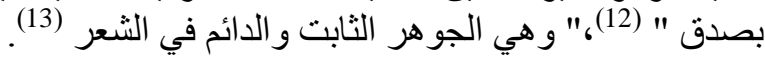

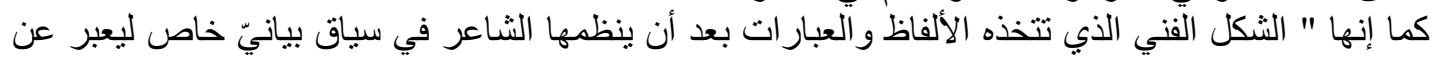

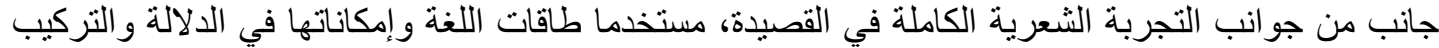

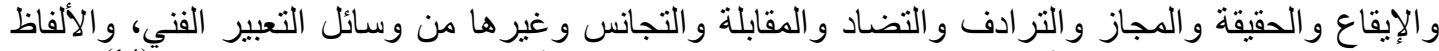

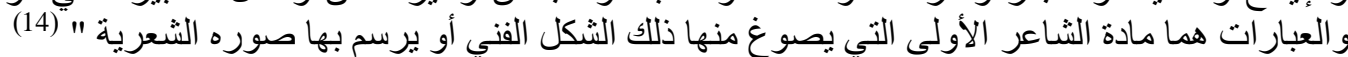

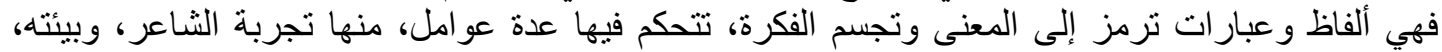

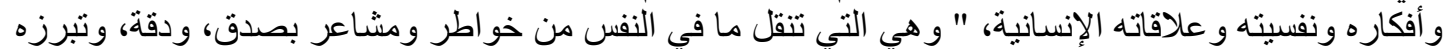
للغير "(15) وصلاح فضل بقر أ الصورة بشكل آخر" هي الثكل البصري المتعين بمقدار ما هو المتخيل الذهني الذي تثيره

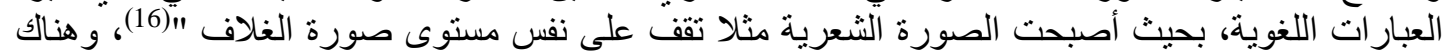
من يرى " أنها صورة حسية من كلمات، استعارية إلى درجة ما، في سياقها نغمة خفيضة من من العاطفة الإنسانية،

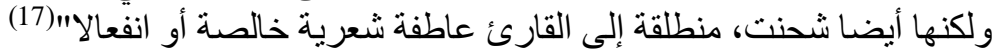

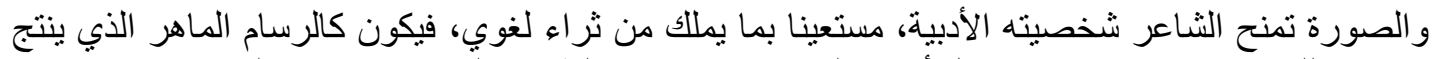

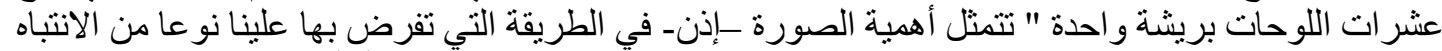

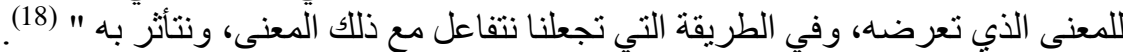

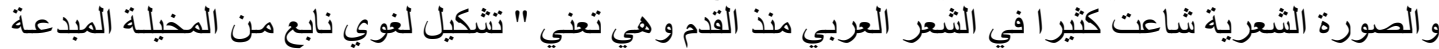

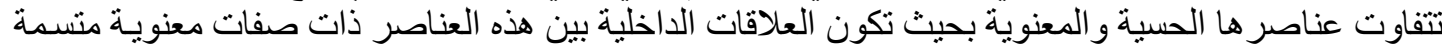

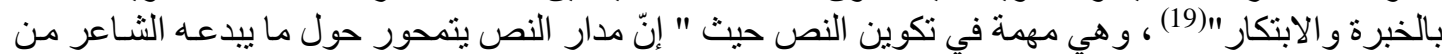

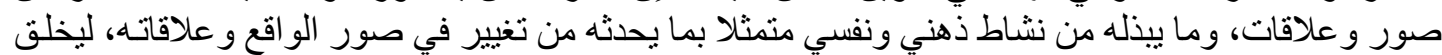

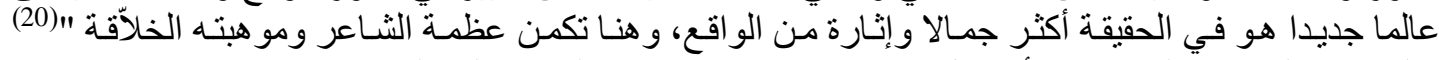

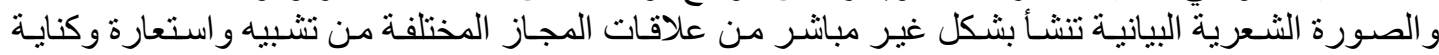
و غير ها. وسنوجز القول في كل واحدة منها:

\section{الصورة الأولى: التشبيهية:}

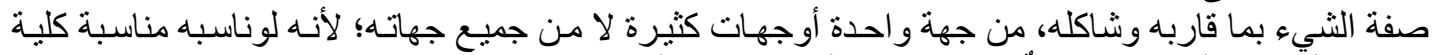

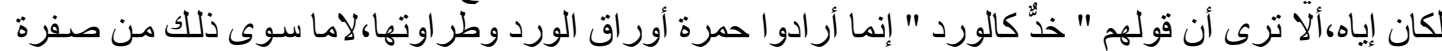
وسطه وخضرة كمائمه..."21) ، أو " هو عقد مماثلة بين أمرين أو أكثر قصد اشتنر اكها في صفة، أو أو أكثر ، بأداة

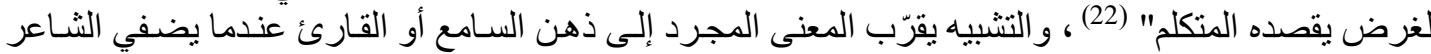

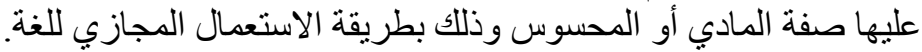

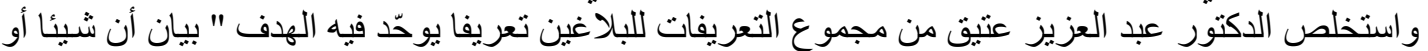

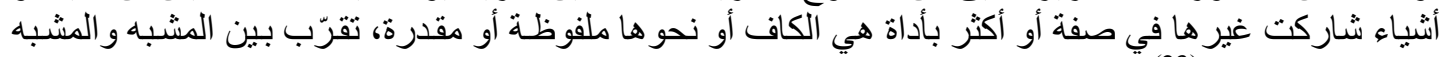

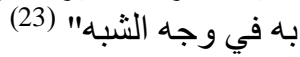
و هو يجسيّد من خلاهل صوره الثبه الحسية الأفكارَ ويجعلها كأنها تُرى، و هذا يعني أنّ للتشبيه أثراً مهماً في تشكيل

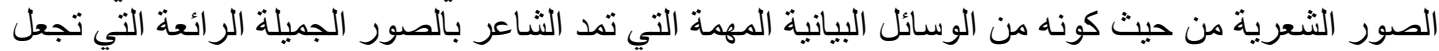
من النص الشعري عذبا جميلا. 


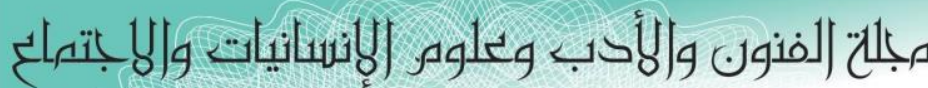
Journal of Arts, Literature, Humanities and Social Sciences

ISSN online: 2414 - 3383

ISSN print: 2616 - 3810

\section{العدد (4O) تموز - يوليو 2019}

ولهذا الفن حضوره الواسع في شعر المرتضى من خلال صوره الدتعددة كالمرسل و المفصل و البليغ و التمثيل...

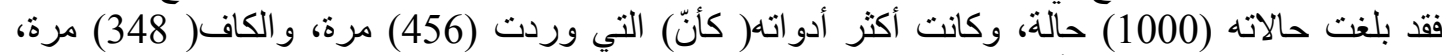

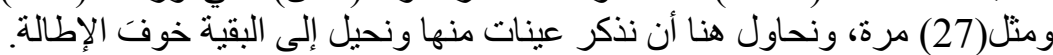

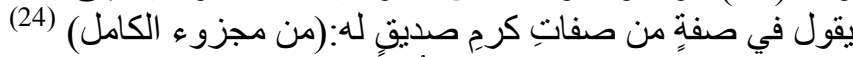

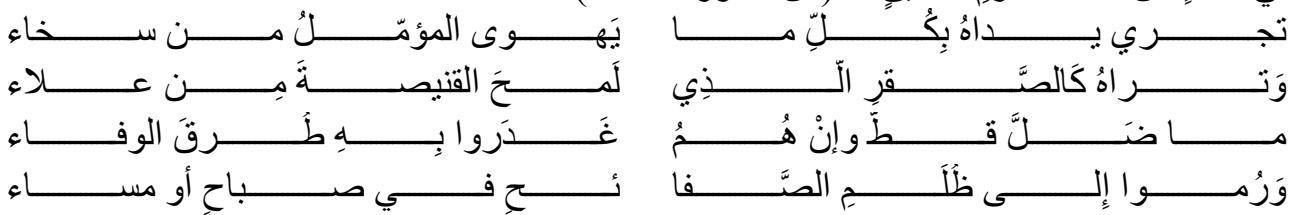

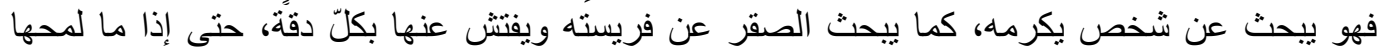

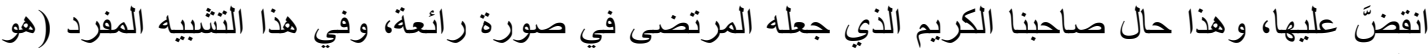

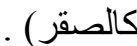

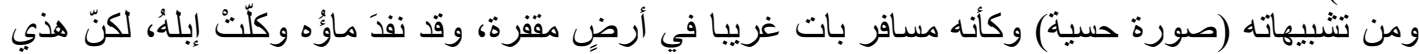

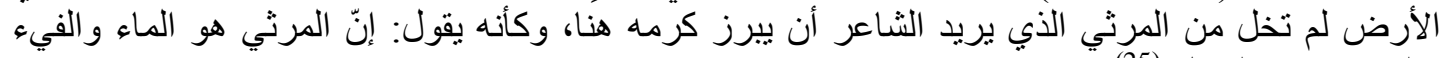

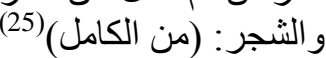

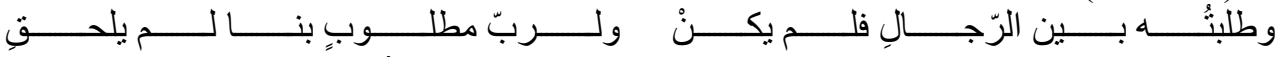

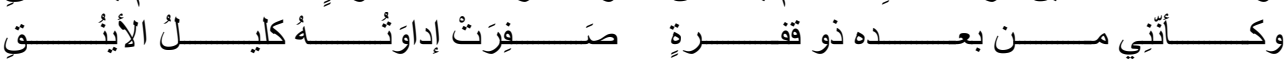

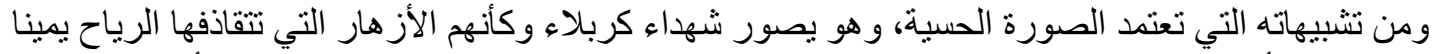

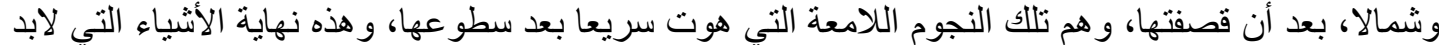
منها: (من الطويل) (26)

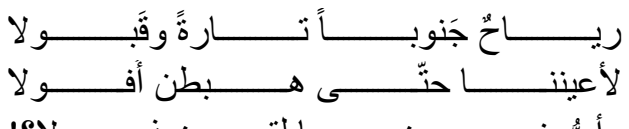

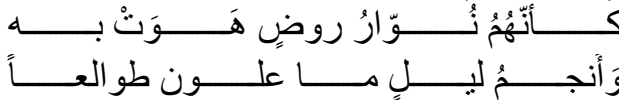

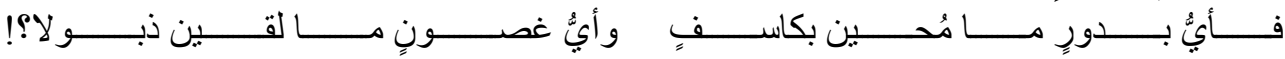

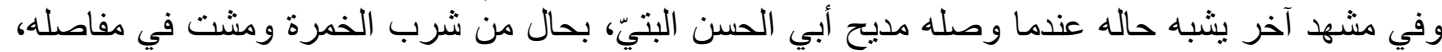

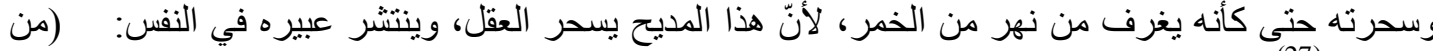
الطويل) (27)

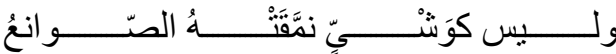

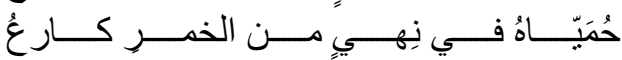

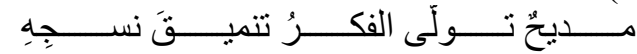

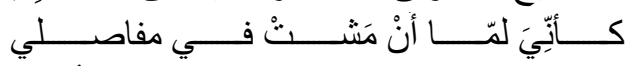

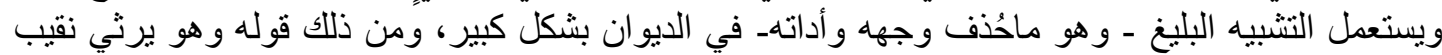

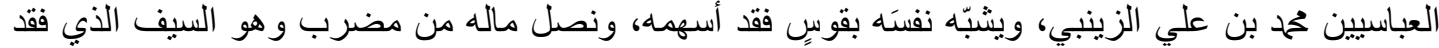

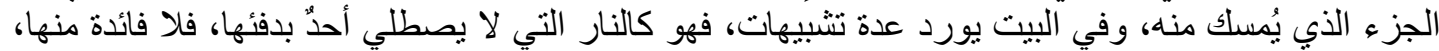

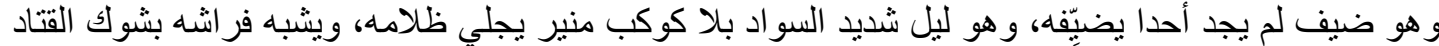

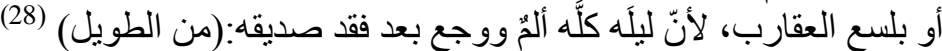

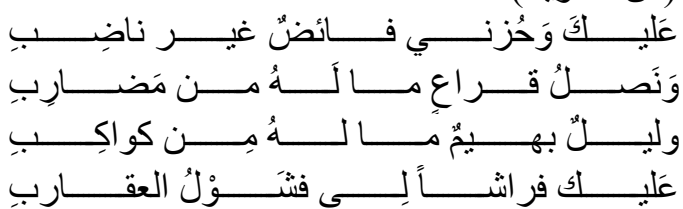

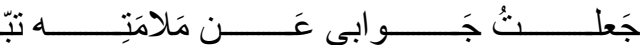

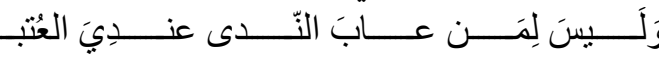

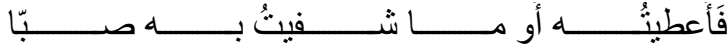

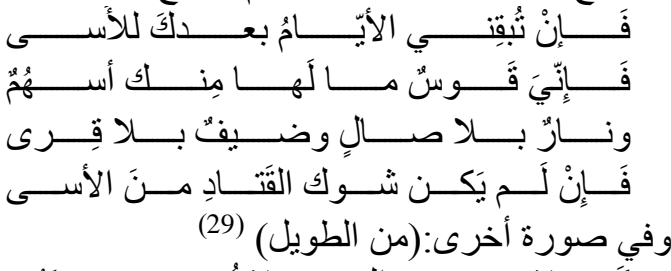

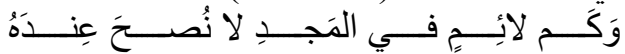

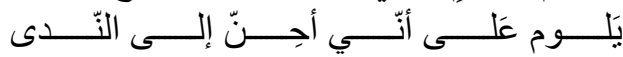

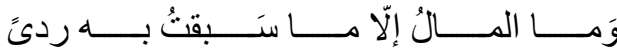




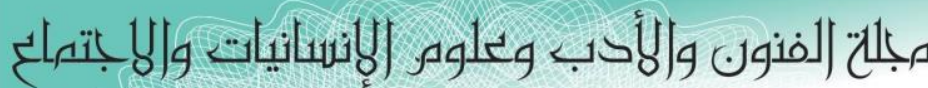
Journal of Arts, Literature, Humanities and Social Sciences

ISSN online: 2414 - 3383

ISSN print: 2616 - 3810

\section{العدد (4O) تموز - يوليو 2019}

جعل المال كالسلاح الذي يدفع به الدوت، أو هو الرد على اللائم الذي يلومه وجعله بديلا عن الكلام لو

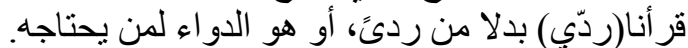

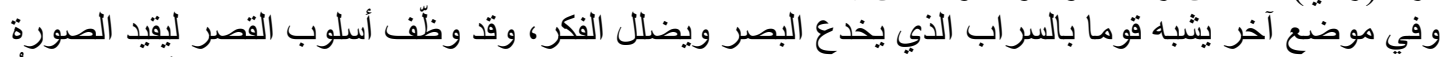

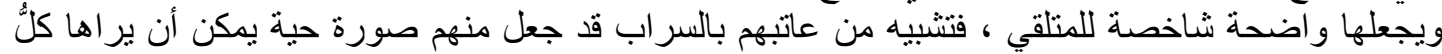

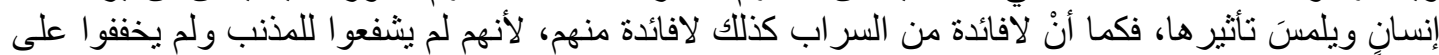

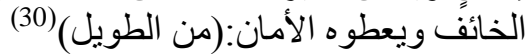

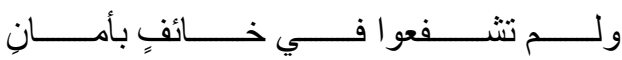

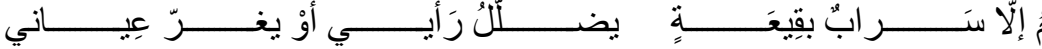

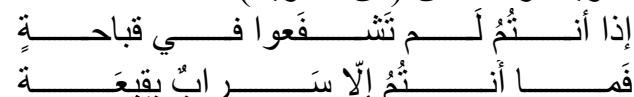

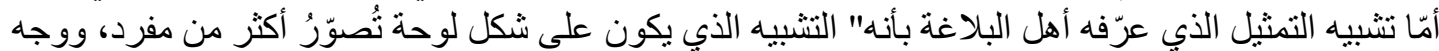

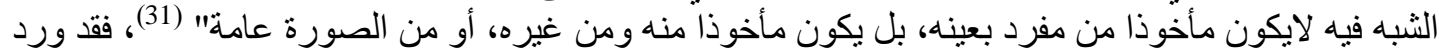

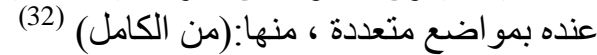

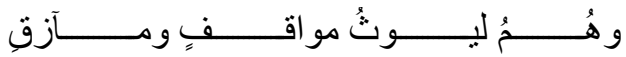

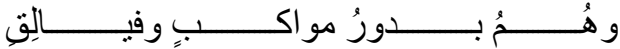

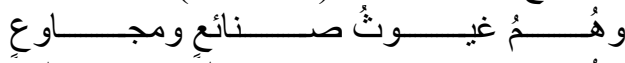

يفتخر بأبائه ويقول: إنهم غوث لكل محتاج وجائع، وهم أسود في كل المو اقف الصعبة، وفي البيت الثاني: هم

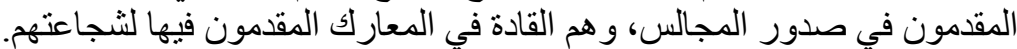

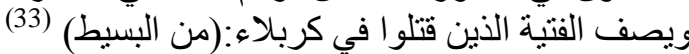
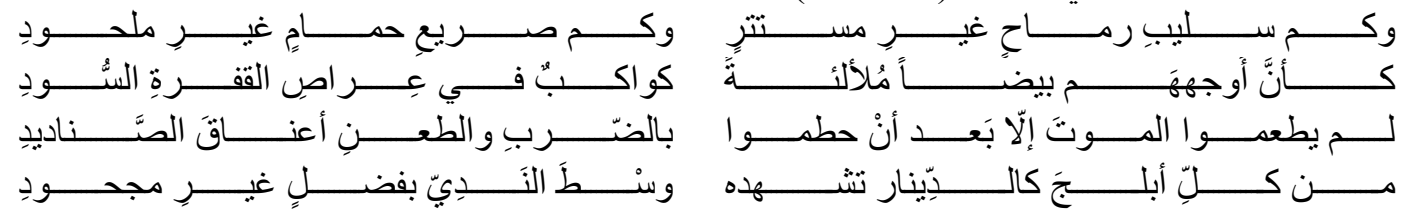

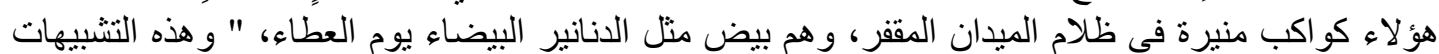

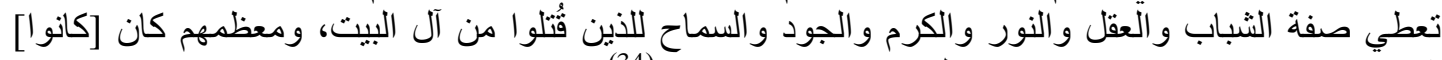

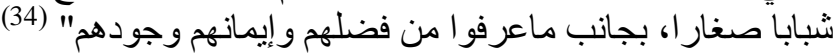

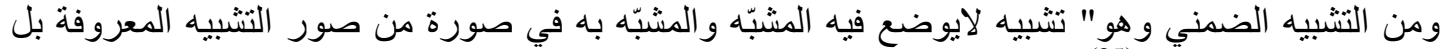

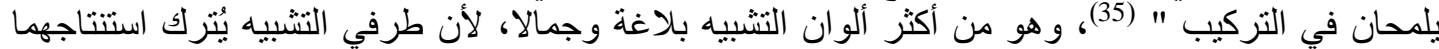

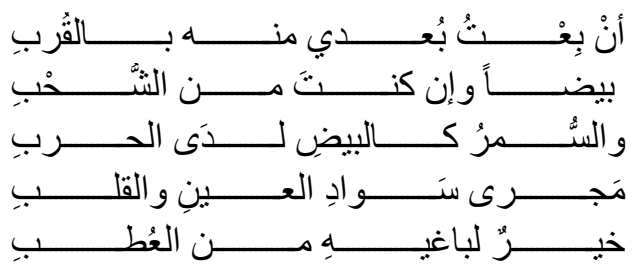

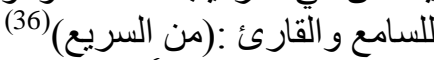

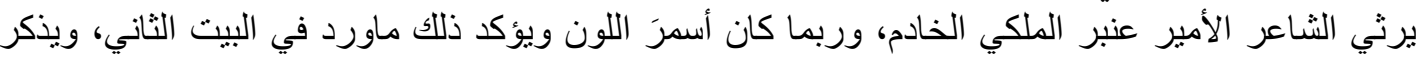

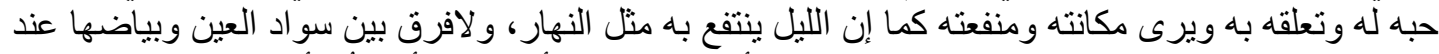

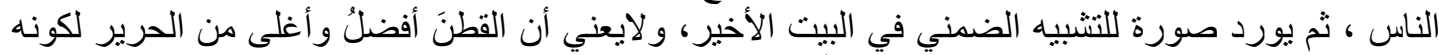

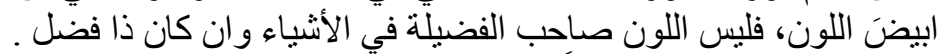

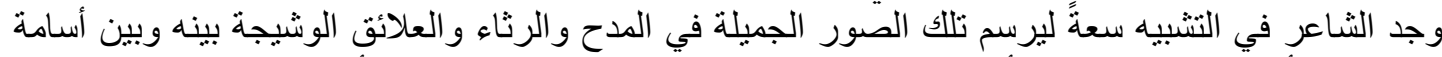

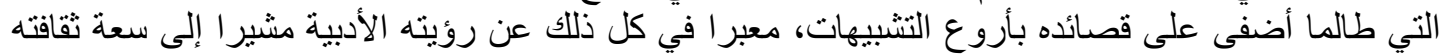
السياسية و الفكرية وتمكنه من أدو اته الفنية. 


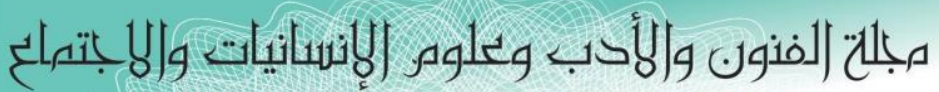
Journal of Arts, Literature, Humanities and Social Sciences

ISSN online: 2414 - 3383

ISSN print: 2616 - 3810

\section{العدد (4O) تموز - يوليو 2019}

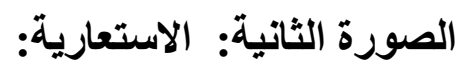

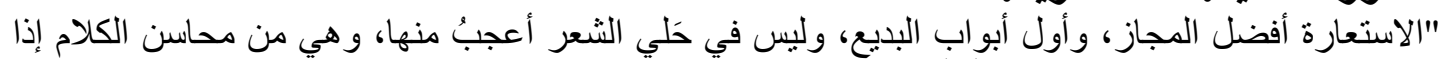

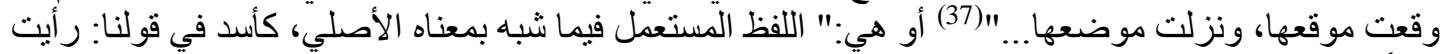

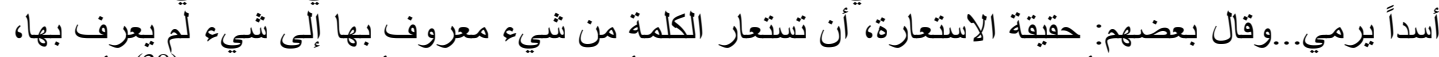

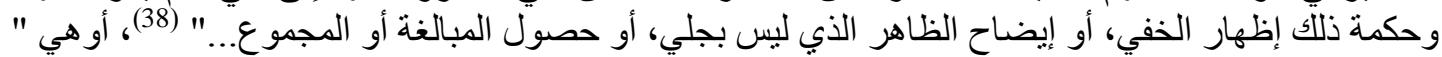

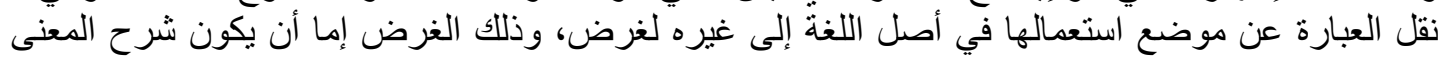

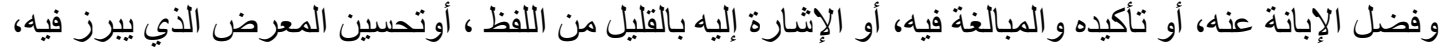

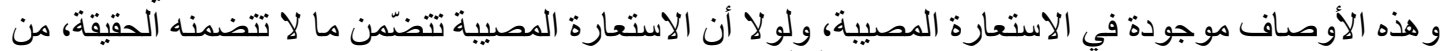

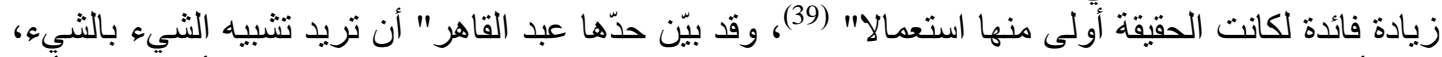

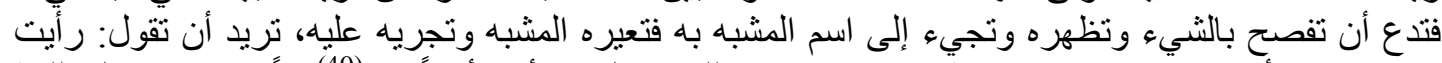

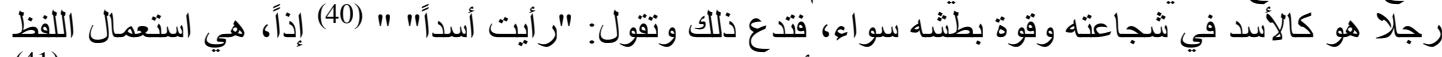

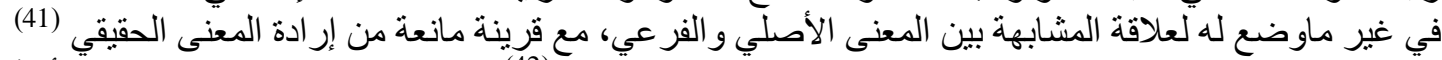

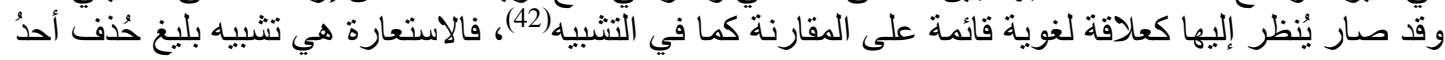

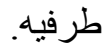

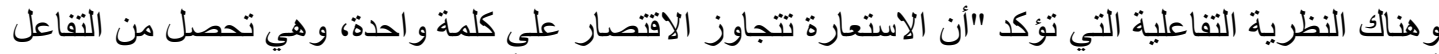
أو التوتر بين بؤرة المجاز، والإطار المحيط بها، وتبين هذه النظرية أن للاستعارة النارة هدفا جماليا، وتثخيصيا،

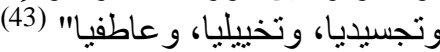

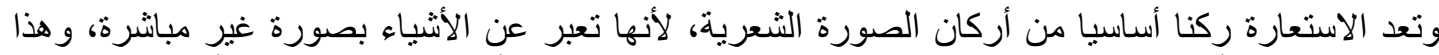

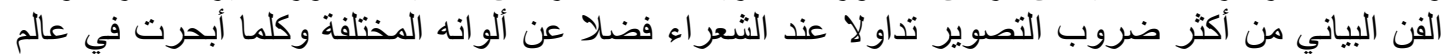

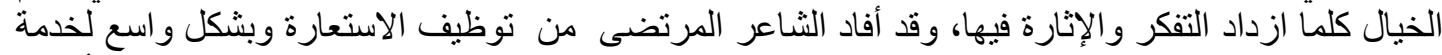

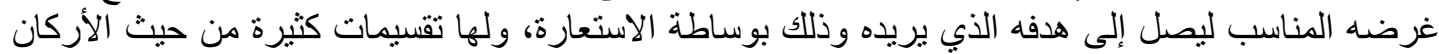

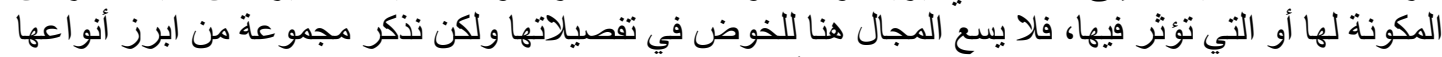
و هها( التصريحية والمكنية) من حيث ذئ ذكر المشبه أو المشبه به فقط في الكلام:

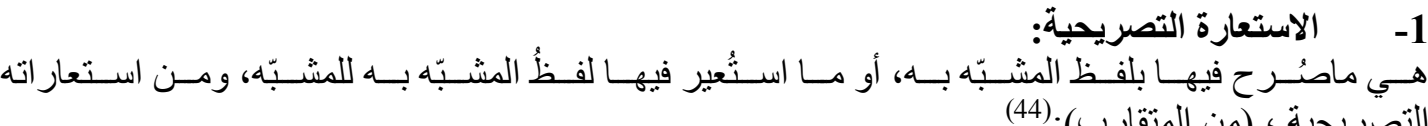

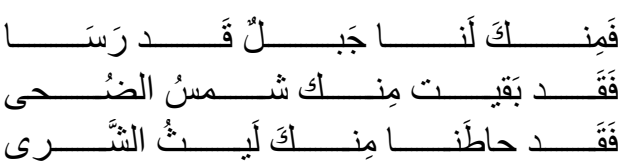

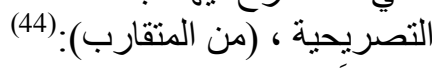

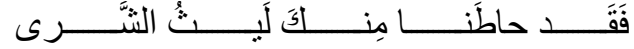

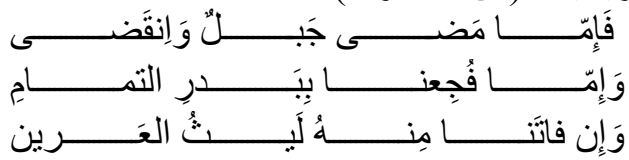

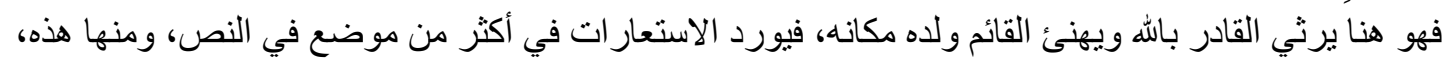

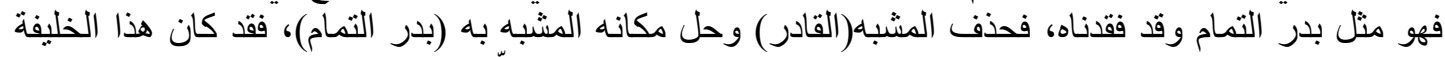

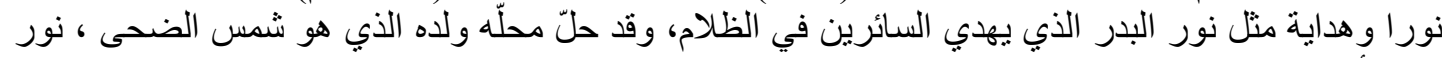
كنور أبيه .

وفي قصيدة أخرى يهنئ فيها فخر الملك بالمهرجان ويمدحه:(من الطويل)(45)

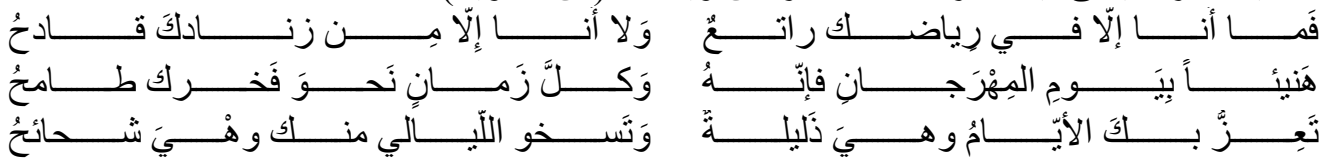

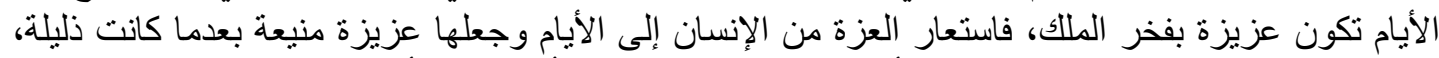

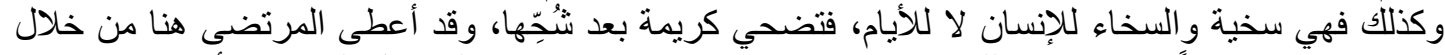

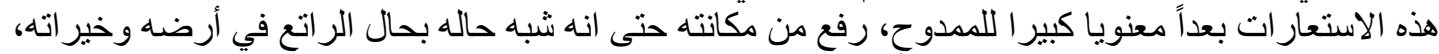
و الذي يستمد منه كل قوته كما في البيت الأول. 


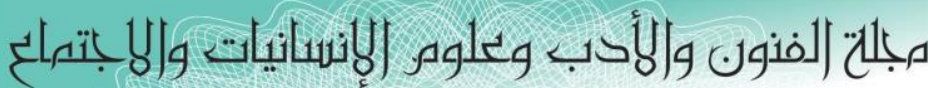
Journal of Arts, Literature, Humanities and Social Sciences

ISSN online: 2414 - 3383

ISSN print: 2616 - 3810

\section{العدد (4O) تموز - يوليو 2019}

ونر اه يمدح الوزير أبا الفرج بن فسانجس في رسالة كتبها إليه:(من البسيط) (46)

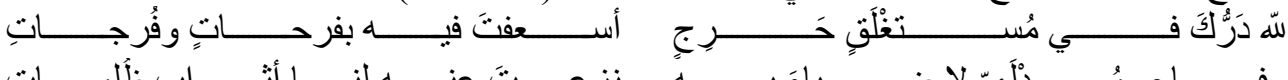

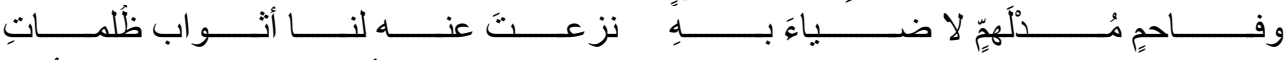

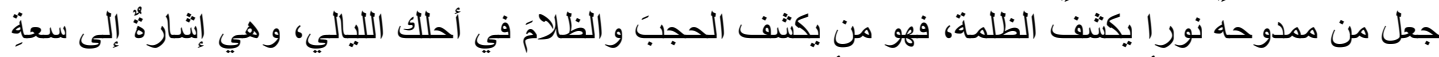

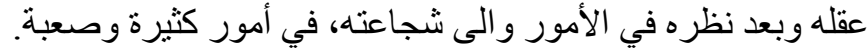

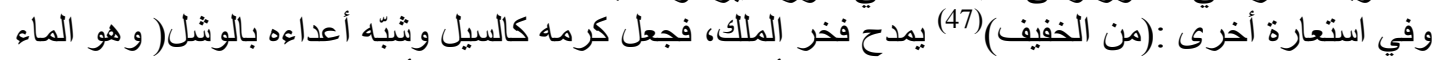

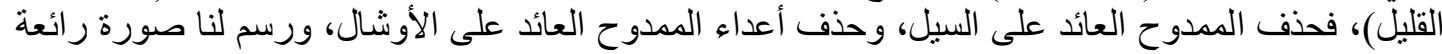

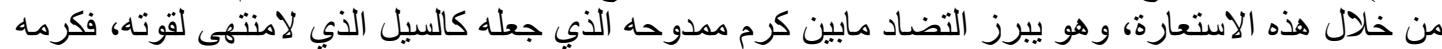

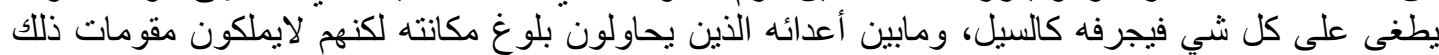
الكرم الطاغي، فأين الأوشال من السيل كالنيل، وماير

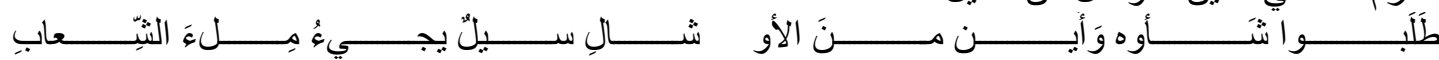

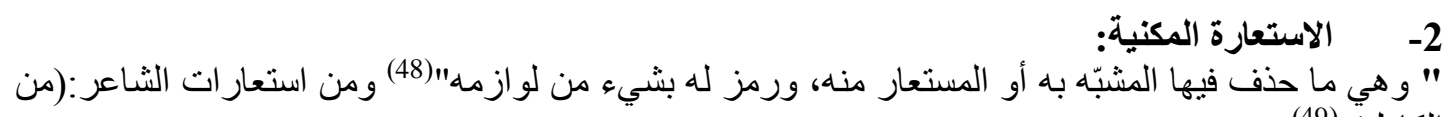

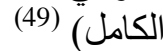

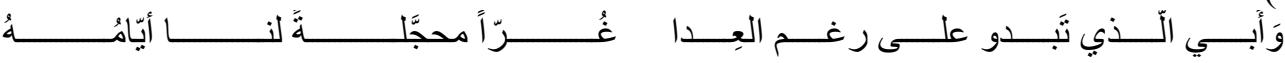

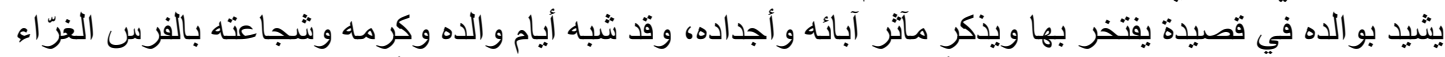

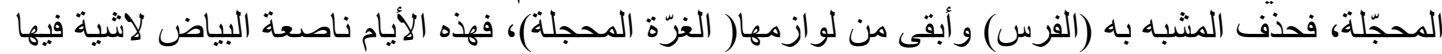
تشوبها، مهما حاول الأعداء طمسها.

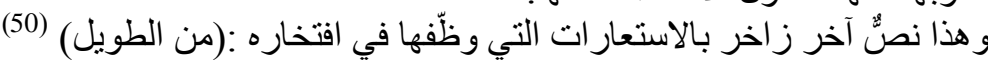

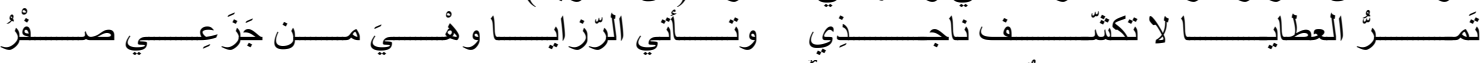

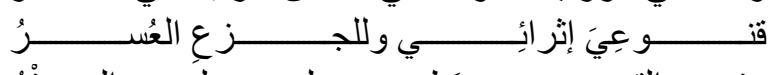

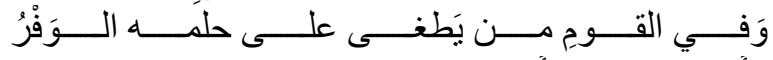

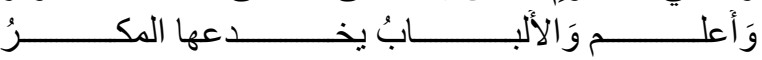

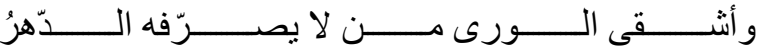

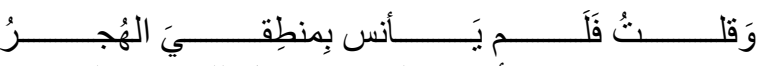

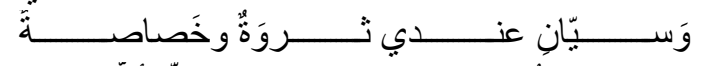

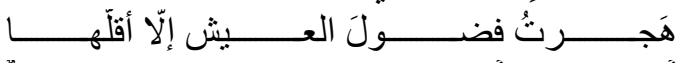

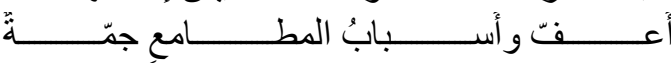

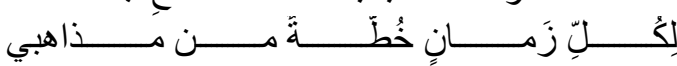

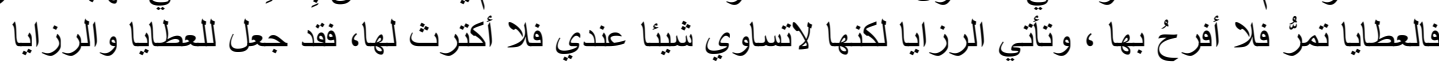

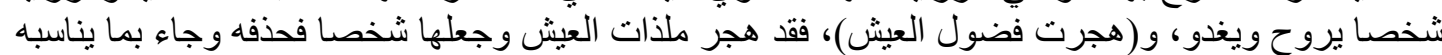

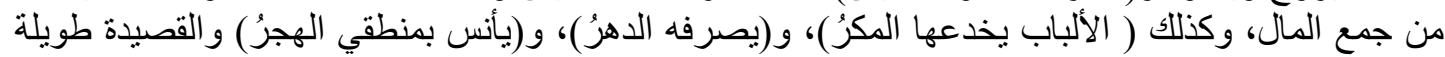

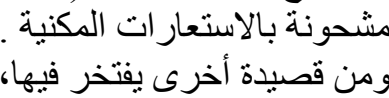

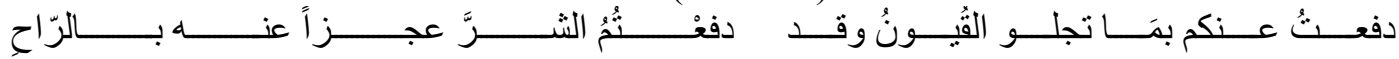

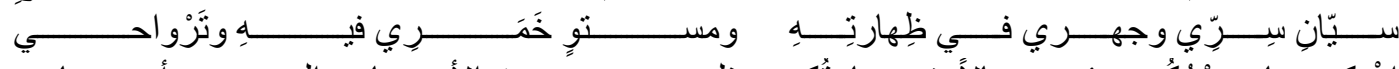

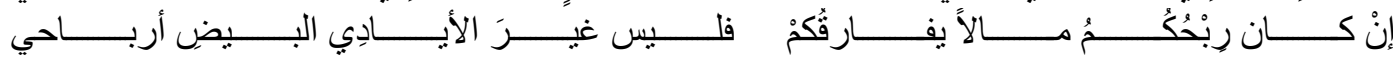

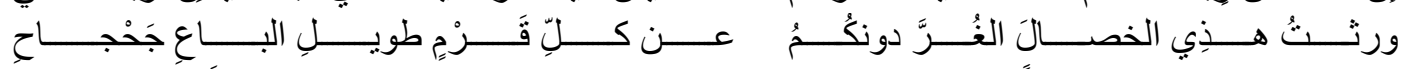

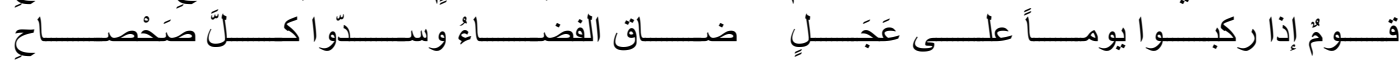

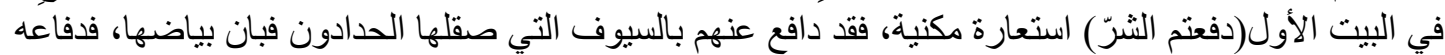

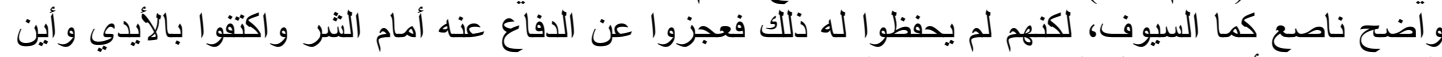

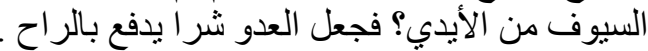

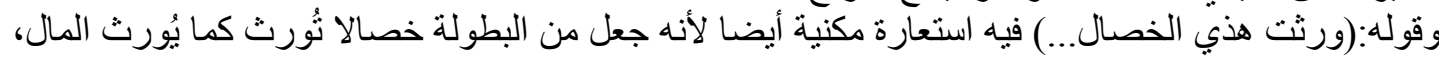

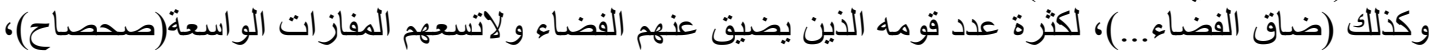




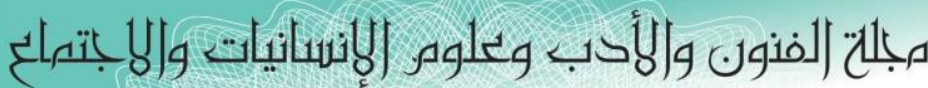
Journal of Arts, Literature, Humanities and Social Sciences

ISSN online: 2414 - 3383

ISSN print: 2616 - 3810

\section{العدد (4O) تموز - يوليو 2019}

وقد أضاف إلى الأبيات كناياتٍ تؤكد نلك الاستعار ات التي جعلت من النص صورة بلاغية مشحونة بكل معاني

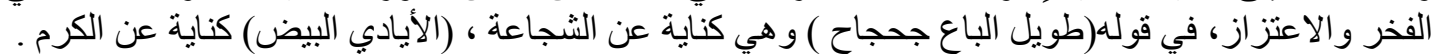
ومن أبياته في الزهد هد بمن لايرضى ولا بقنع بالخير، لكن بيوتهم مليئة بالشر، خالية من الخية الخير : (من السربع)

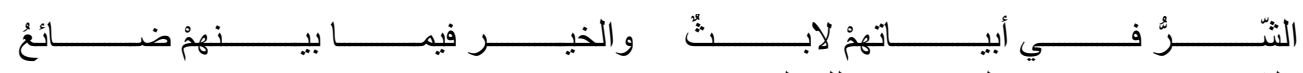

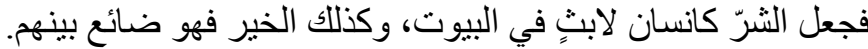

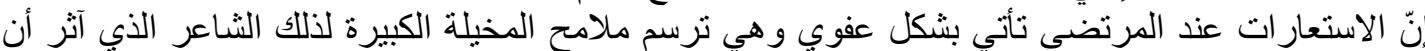

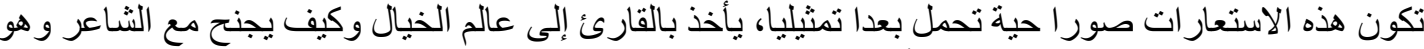
يتلقى هذه الصور البلاغية بشكل ممتع و أخّاذ.

\section{الصورة الثالثة : الكنائية:}

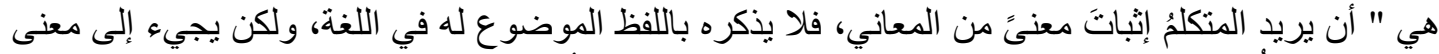

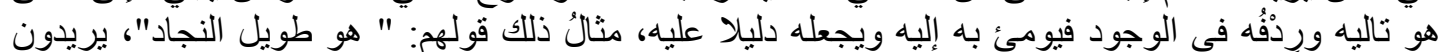
طويل القامة "(53). أما ابن الأثير فقد خالف الكثير في تعريفها فقال:" فحدّ الكناية الجامع لها هو أنها كل لفظة دلت على معنى

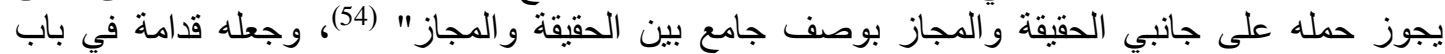
الإرداف، فالثاعر لايأتي باللفظ الدال على المعنى مباشرة، و إنما يأتي بلفظ يدل على على معنى هو ردفه وتابع لله

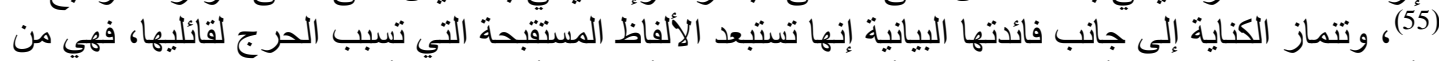

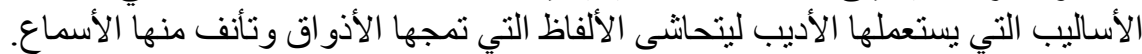

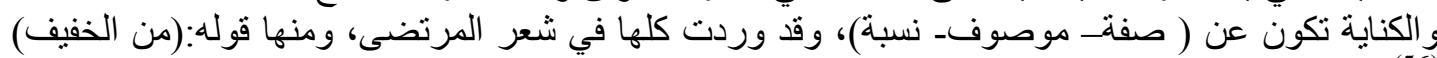

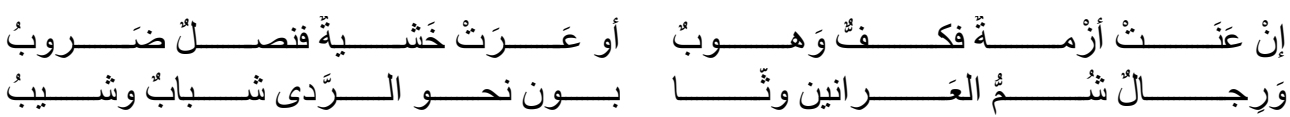
شُمُّ العر انين، هؤلاء الأبطال من أهل العزة والمنعة شامخة أنوفهم، وقد كنى بذلك عن البطولة والفتوة، في وني

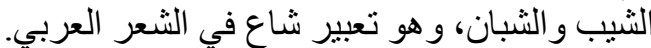

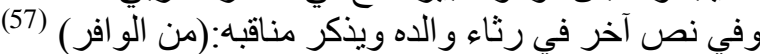

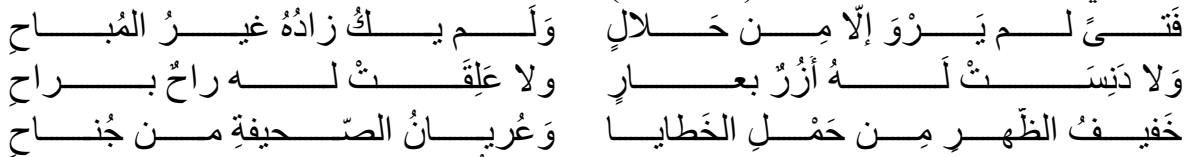

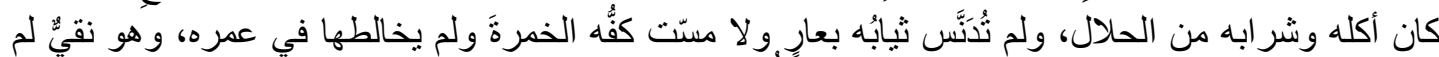

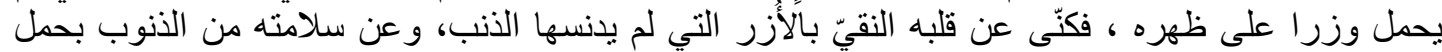
الخطايا. وفي قصيدة يهنيء أباه ويتنقل عبر أبياتها وهي مشحونة بالعديد من صفاته التي طالما كرر ها المرتضى، وهي وهي

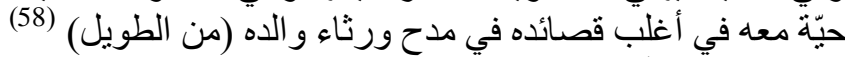

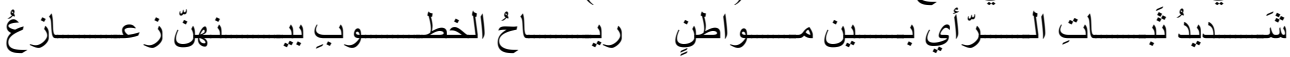
فتر اه في كل الأماكن و المواطن الصعبة ثابت الرأي، و(رياح الخطوب) كناية عن الصعوبات الثديدة تداخل الأمور و اختلاطهها. وتتو اللى الكنايات بشكل كبير في الديوان ومن ذللك مانر اه في هذه الصورة التي رسمها لبيت الكرم الذي عاش الش

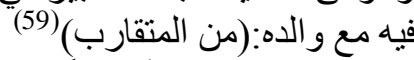
بِكَ بِالكثي

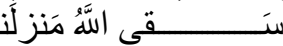




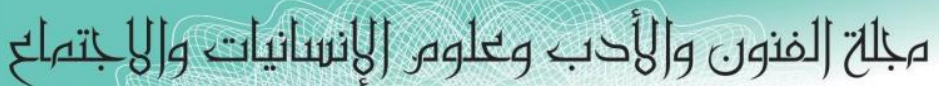
Journal of Arts, Literature, Humanities and Social Sciences

ISSN online: 2414 - 3383

ISSN print: 2616 - 3810

\section{العدد (4O) تموز - يوليو 2019}

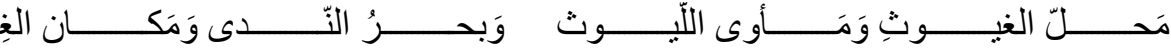

فنجد الكناية عن صفات متعددة في البيت الثاني، وهي عن غوث الملهوف وكَّ وعن القوة والبطولة و وعن الكرم

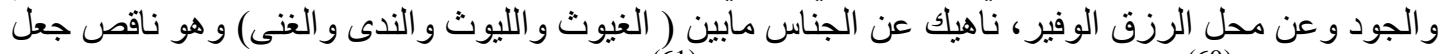

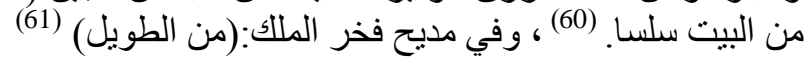

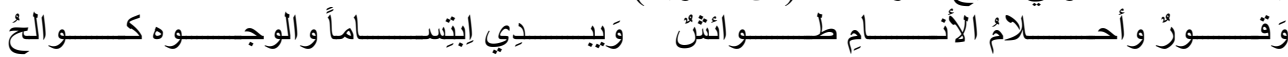

رجاحة عقله ووقاره مع طيش عقول الآخرين، وثباته فهو يبدي ابتساما كناية عن شجاعته في الحرب عندما

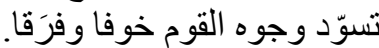

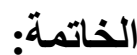

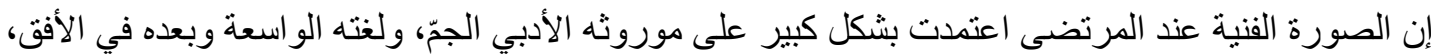

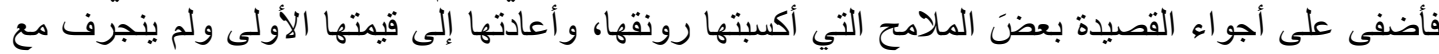

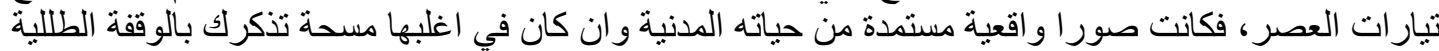
و وجر ان ديار الأحبة و لاسيما في مقدمات قصات التصائده.

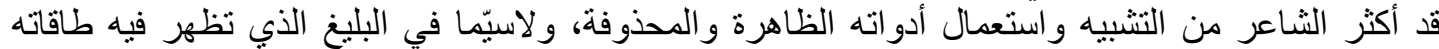

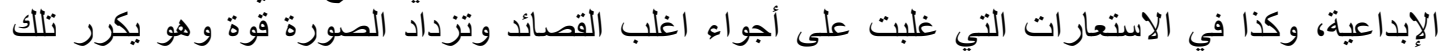

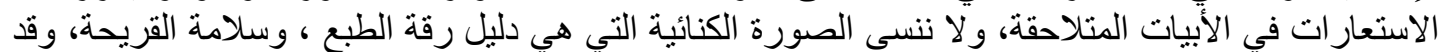

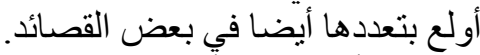

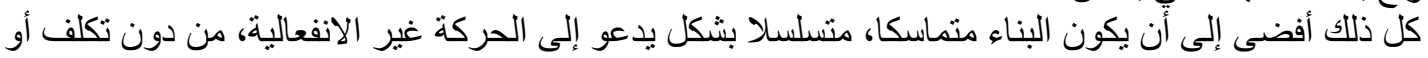

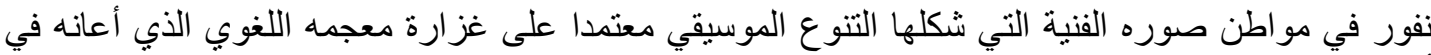

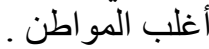

الذهوامش

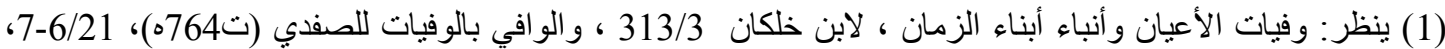

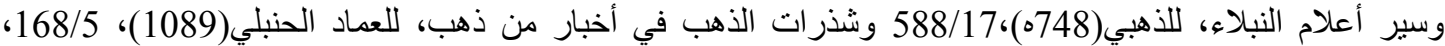

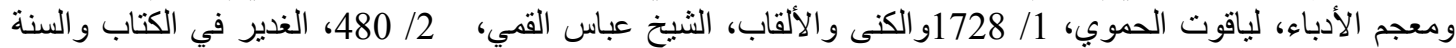

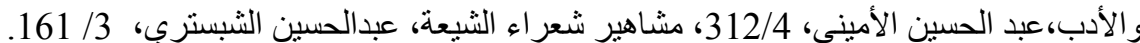

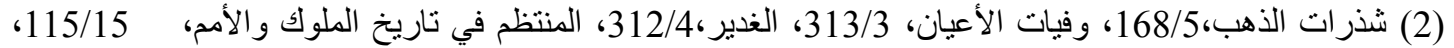

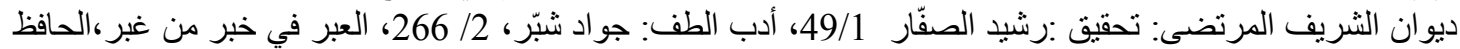

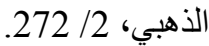

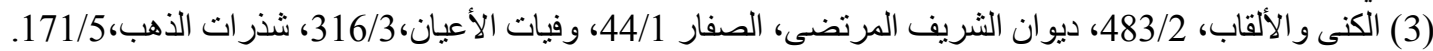

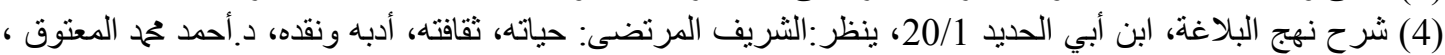

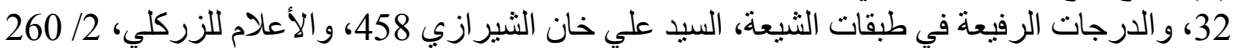

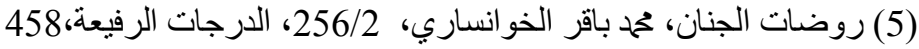

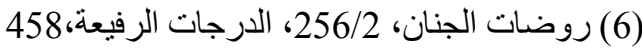

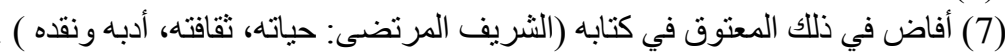

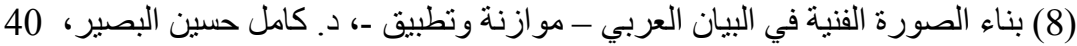

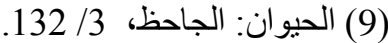

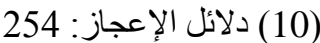

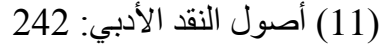
(12) تذوق النص الأدبي: 101 


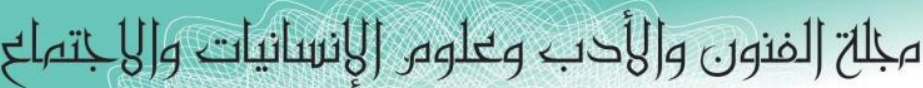

Journal of Arts, Literature, Humanities and Social Sciences

ISSN online: 2414 - 3383

ISSN print: 2616 - 3810

العدد (4O) تهوز - يوليو 2019

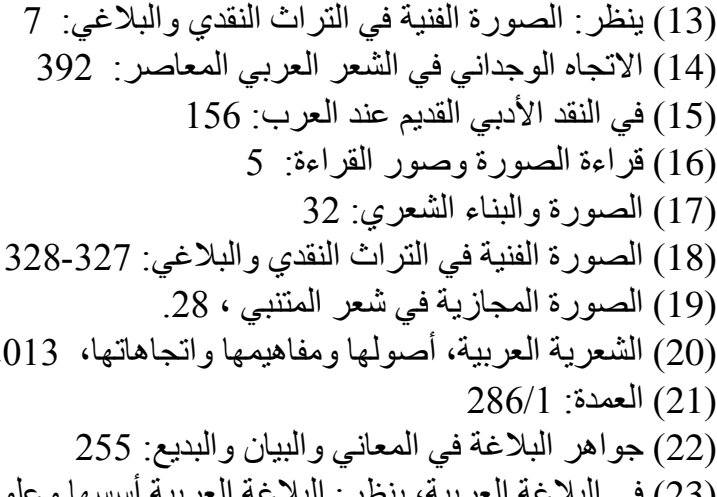

(23) في البلاغة العربية، بنظر : البلاغة العربية أسسهاو ولومها وفنونها :161/2، معجم البلاغة العربية: 296

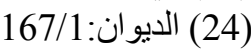

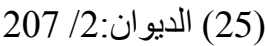

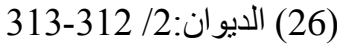

(27)

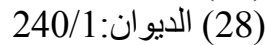

207/1: (29) الديوان

(30) الديوان:561/2) (30) الايوان (30)

(31) البلاغة العربية أسسها و علومها وفنونها: 186/2، ينظر : مدخل إلى البلاغة العربية: 154

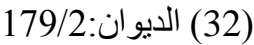

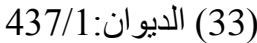

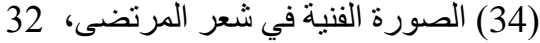

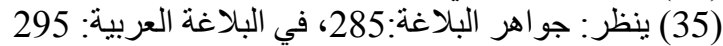

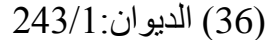

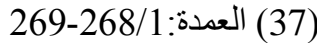

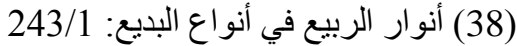

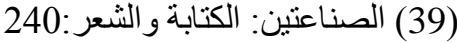

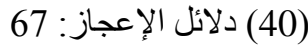

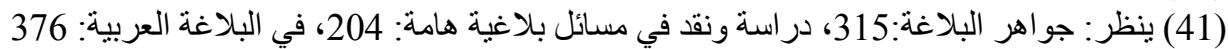

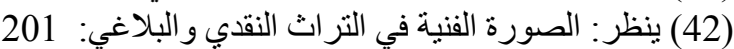

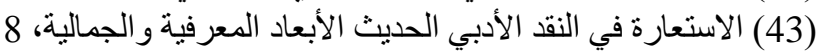

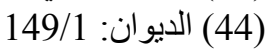

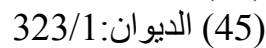

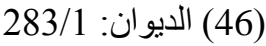

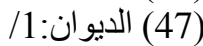

(48) في البلاغة العربية: 373 العان 3972

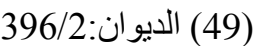

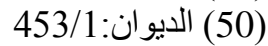

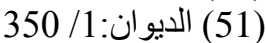

(52) الديوان:60/2 (52)

(53) دلائل الإعجاز : 66 (52)

(54) المثل السائر : 52/3 


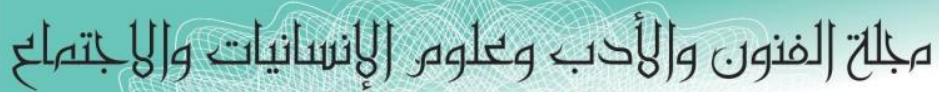

Journal of Arts, Literature, Humanities and Social Sciences

ISSN online: 2414 - 3383

ISSN print: 2616 - 3810

العدد (4O) توز - يوليو 2019

1. الاتجاه الوجداني في الثعر العربي المعاصر : د. عبد القادر القط، مكتبة الثباب، مصر، ط1، 1988

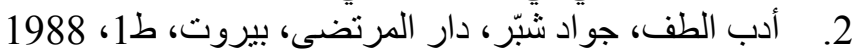

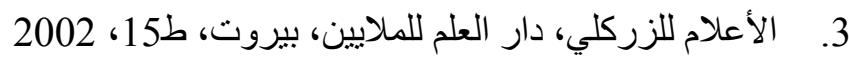

4. الاستعارة في النقد الأدبي الحديث الأبعاد المعرفية والجمالية: د. يوسف أبو العدوس، الأهلية للنشر،

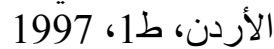

5. البلاغة العربية أسسها وعلومها وفنونها: عبد الرحمن الميداني، دار القلم- دمثق، دار الثشاميةـ بيروت،

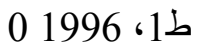

6. بناء الصورة الفنية في البيان العربي - موازنة وتطبيق ـ، د. كامل حسين البصير، مطبعة المجمع العلمي

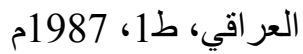

7. تذوق النص الأدبي: د.سامي يوسف أبو زيد، دار المسرّة، الأردن، ط1، 2012

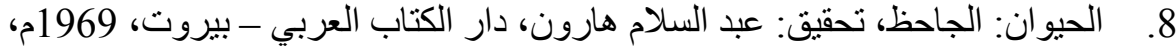
9. الدرجات الرفيعة في طبقات الثيعة، السيد علي خان الثير ازي(1130هان)، مؤسسة الوفاء، بيروت، ط2، 1983

10. ديوان الشريف المرتضى: تحقيق :رشيد الصفّار، دار البلاغة، بيروت، ط1، 1998 11. روضات الجنان، محمد باقر الخو انساري، المطبعة الحيدرية، طهران، ط1، 1390هـ 12. سير أعلام النبلاء، للذهبي(748ه)، تحقيق: شعيب الأرناؤوط، محم نعيم العرقسوسي، مؤسسة الرسالة،

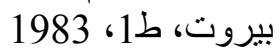

13. شذرات الذهب في أخبار من ذهب، للعماد الحنبلي(1089)، تحقيق عبد القادر الأرناؤوط ومحمود

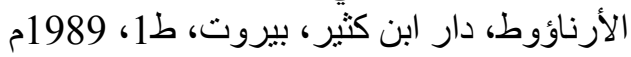

14. شرح نهج البلاغة، ابن أبي الحديد، تحقيق : ححم إبر اهيم، دار الكتاب العربي، بغداد ، ط1، 2007 15. الثريف المرتضى: حباته، ثقافته، أدبه ونقده، د.أحمد محمد المعتوق ،المؤسسة العربية للدراسات والنشر، لئرة

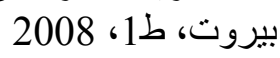




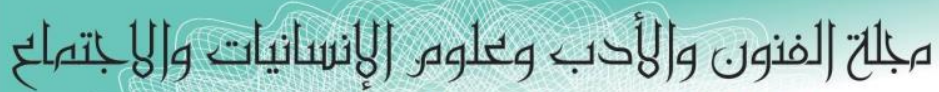
Journal of Arts, Literature, Humanities and Social Sciences

ISSN online: 2414 - 3383

ISSN print: 2616 - 3810

العدد (4O) توز - يوليو 2019

16. الثعرية العربية، أصولها ومفاهيمها و اتجاهاتها: د. مسلم حسين حسب، ط: 2013، مطبعة ضفاف، السعودية.

17. الصناعتين: الكتابة والثعر: أبو هلال العسكري، تحقيق: علي محمد البجاوي- تحمح أبو الفضل إبراهيم، المكتبة العصرية، بيروت، ط1، الكنابة 2006

18. الصورة الفنبة في التراث النقدي والبلاغي: د. جابر عصفور، المركز الثقافي العربي، بيروت، ط3، 1992

19. الصورة الفنية في شعر المرتضى، دراسة نقدية: طاهرة عبد الخالق اللواتية، مؤسسة الانتشار العربي، بيروت، ط1، 2015

20. الصورة المجازية في شعر المتنبي، خليل رشيد فالح، رسالة دكتوراه، كلية الآداب - جامعة بغداد، 1985

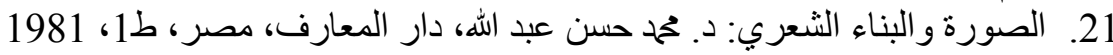
22. العبر في خبر من غبر،الحافظ الذهبي،(748ه)،تحقيق: ابو هاجر محمد زغلول، دار الكتب العلمية ، بيروت، ط1، 1985

23. الغدير في الكتاب والسنة والأدب،عبد الحسين الأميني، مؤسسة الأعلمي للمطبوعات، بيروت، ط1، 1994

24. في البلاغة العربية، علم المعاني، البيان، البديع: د. عبد العزيز عتيق، دار النهضة العربية، بيروت، ط1،

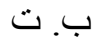

25. في النقد الأدبي القديم عند العرب: د. مصطفى عبد الرحمن إبر اهيم، مكة للطباعة، مصر ، ط1، داء، 1998

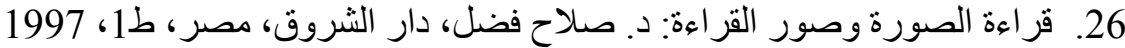

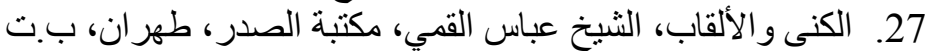

28. مشاهير شعر اء الثيعة، عبدالحسين الثبستري، مطبعة ستارة، قم، ط1، 1421ه

29. معجم الأدباء، لياقوت الحموي، تحقيق: د. إحسان عباس، دار الغرب الإسلامي، بيروت، ط1، 1993

30. معجم البلاغة العربية: د. بدوي طبانة، دار المنارة، جدة، دار الرفاعيـ الرياض، ط3 3.

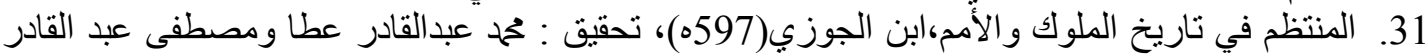
عطا، دار الكتب العلمية، بيروت، طارئ، 1995

32. الوافي بالوفيات للصفدي (ت764ه)،تحقيق : أحمد الأرناؤوط وتركي مصطفى، دار إحياء التراث

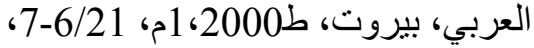

33. و وفيات الأعبان و أنباء أبناء الزمان ، لابن خلكان(ت 681ه)، تحقيق : د.إحسان عباس، دار صادر بيروتـ لبنان، ط1، 